\title{
A CASE OF REITER'S SYNDROME TREATED WITH CHLORAMPHENICOL*
}

\author{
BY \\ DAVID WHEATLEY
}

\author{
Twickenham, Middlesex
}

My reason for publishing yet another account of a condition which has perhaps received publicity out of proportion to its importance, is that I have been unable to trace any description in the British literature of treatment with this antibiotic. Elsewhere I could find only one published case treated with chloramphenicol (Findlay and Willcox, 1951), although Harkness (1950a) refers to another case treated by Harman, which as far as I can ascertain has never been published.

\section{Aetiology}

Three organisms have been incriminated in this condition, as well as the allied one of abacterial pyuria which Harkness (1950b) considers to be an identical illness. The organisms are :

(1) a virus of the lymphogranuloma-psittacosispneumonitis group.

(2) pleuropneumonia-like (L) organisms.

(3) a spirochaete (Czekalowski and Horne, 1951).

The main weight of evidence seems to be in favour of a virus, of which the L organisms may be but a transitional stage. The infection is probably venereal in origin, but a well-defined group of cases follows dysenteric infection (Pastinszky, 1947).

\section{Treatment}

Although numerous methods have been used, treatment remains on the whole unsatisfactory. Before the antibiotic era, pyrotherapy was probably the most successful form of treatment. Of drugs then advocated, sulphonamides, arsenicals, and gold were all of dubious value. More recently penicillin has proved ineffective, and there are conflicting reports as to the effectiveness of streptomycin and aureomycin. Even ACTH and cortisone have been used in this disease and some success was claimed for them by Ogryzlo and Graham, 1950. It seems surprising that chloramphenicol, a drug used in virus infections, should not have received more mention in the literature. Findlay and Willcox (1951) used a dosage of $0.25 \mathrm{~g}$. three times daily for 3 weeks in their case, and rapid resolution of conjunctivitis, arthritis, and

\footnotetext{
* Received for publication January 1, 1953.
}

urethral discharge resulted, although threads in the urine and keratodermia of the penis persisted for 55 days. Harman's case (Harkness, 1950a) was treated with 2 g. chloramphenicol three times daily for one day, followed by $1 \mathrm{~g}$. three times daily for 7 days, but the symptoms became worse during treatment. I have described a case of persistent phosphaturia, which responded rapidly without recurrence to chloramphenicol given for a concurrent pertussis infection (Wheatley, 1951). I could find no explanation for this, other than that the infection was abacterial. As chloramphenicol is cheaper than aureomycin and less toxic than streptomycin, it would seem to be a reasonable choice for the therapy of Reiter's syndrome ; and a case so treated is described below.

\section{Case Report}

A bachelor aged 38 consulted me on October 18, 1952 , complaining of frequent and painful micturition of $12 \mathrm{hrs}$ duration. The onset had been preceded by a slight white discharge on one morning only. A midstream specimen of urine was sent to the laboratory and then treatment was instituted with sulphadimidine, $1 \mathrm{~g}$. 6-hourly. There was no improvement.

October 22.- - He developed a severe non-purulent bilateral conjunctivitis. The report on the urine showed a sterile pyuria, with $100 \mathrm{mg}$. per cent. protein and many pus cells. The significance of the conjunctivitis was not immediately appreciated and sulphonamide therapy was continued.

October 27.- There were still many pus cells in the urine, no albumin, but a scanty growth of $B$. coli. Ziehl-Neelsen staining for tubercle bacilli was negative on both occasions.

October 31.- He was questioned about joint pains and mentioned a little stiffness in the right knee-joint. Sulphadimidine was discontinued and chloramphenicol substituted in a dosage of $0.75 \mathrm{~g}$. three times daily, reducing to $0.5 \mathrm{~g}$. after 2 days.

November 3.- - He entered the surgery limping badly, with both knee joints swollen and inflamed, and an effusion in the right one. Both conjunctivitis and urinary symptoms however, had completely resolved and did not recur again. Erythrocyte sedimentation rate $17 / 1 \mathrm{hr}$ (Westergren). Two days later, the knees were worse and 
he was obliged to retire to bed. His temperature was $100^{\circ} \mathrm{F}$.

November 7.- He was apyrexial and very much better ; the inflammation of the knees was subsiding rapidly. Examination of the urine showed " albumin $20 \mathrm{mg}$. per cent., a few leucocytes, no organisms, no spirochaetes on dark-ground examination" (This had been requested earlier but had been overlooked by the laboratory). There was continued improvement and two weeks later treatment was discontinued and he was able to return to work.

He has since remained symptom-free, but the urine on December 1 still contained an occasional pus cell, with no albumin and growth of a few colonies of enterococci only. Other investigations were :

Culture for tubercle bacilli negative.

Wassermann reaction negative.

Kahn test negative.

Gonococcal complement-fixation test negative.

Agglutination tests of serum with polyvalent Flexner and Sonne organisms negative.

Careful questioning elicited a history of sexual intercourse at the beginning of October ( 3 weeks before onset) and 2 months previous to that, only. There was no history of diarrhoea either in the patient or in other members of the household.

\section{Discussion}

This case was not investigated as fully as would have been possible in a special clinic or hospital, but the triad of Reiter's syndrome was well exhibited, although keratodermia blenorrhagica did not develop, and the presenting symptoms were of a cystitis rather than urethritis. Repeated examination of the urine revealed no organisms except on one occasion when a few $B$. coli were cultured. These can be dismissed as contaminants, particularly as they were found after treatment with sulphadimidine and not before. Findlay and Willcox persistently cultured Staph. albus from the urine of their case, but this persisted after treatment and resolution of symptoms, and was presumably a contaminant.

Chloramphenicol would appear to be a logical drug to use in Reiter's syndrome. In this case it resulted in a rapid amelioration of symptoms and a return to work by the patient after only 3 weeks' illness, whereas in the absence of specific therapy the infection has been known to persist for many months.

\section{Summary}

A case of Reiter's syndrome, showing the triad of cystitis, conjunctivitis, and arthritis, is described. The case was treated with chloramphenicol with rapid resolution of symptoms and pyuria. No publication of such a case treated with chloramphenicol could be traced in the English literature, although one such report had appeared in America.

\section{REFERENCES}

Czekalowski, J. W., and Horne, G. O. (1951). Brit. med. J., 2, 879. Findlay. G. M., and Willcox, R. R. (1951). Amer. J. Syph., 35, 582 Harkness, A. H. (1950a). "Non-gonococcal Urethritis", p. 126. Livingstone, Edinburgh.

(1950b). Ibid., p. 96.

Ogryzlo, M. A., and Graham, W. (1950). J. Amer. med. Ass., $144,1239$.

Pastinszky, E. (1947). Acta derm-venereol., Stockh., 27; 415.

Wheatley, D. (1951). Brit. med. J., 2, 1221. 